\title{
MODIFICATIONS OF THE WEINBACH METHOD FOR THE DETER- MINATION OF SODIUM IN SERUM
}

\author{
BY
}

\author{
F. S. FOWWEATHER AND W. N. ANDERSON \\ Department of Chemical Pathology, University of Leeds
}

(RECEIVED FOR PUBLICATION, FEBRUARY, 1948)

The Weinbach (1935) method, based on that of Barber and Kolthoff $(1928,1929)$, involves the precipitation of sodium as the triple salt uranyl zinc sodium acetate in the presence of alcohol, and subsequent titration of this salt with sodium hydroxide, using phenolphthalein as indicator. We have found the end-point of the titration to be unsatisfactory, and have preferred colorimetric methods for this part of the determination. The colorimetric procedure, described by McCance and Shipp (1931), which depends on the colour produced by the addition of potassium ferrocyanide to a solution of the uranyl zinc sodium acetate in the presence of a small quantity of acetic acid, was found reasonably satisfactory so long as we used visual colorimetry, and compared the solution to be determined with a standard solution similarly treated, at the same time. When, later, we began to use photo-electric methods, difficulties arose owing to the rather rapid changes which take place in the intensity of the colour produced by this method. Indeed, the adoption of modern methods of colour measurement which do not involve direct comparison of two solutions made up under similar conditions at the same time has brought to light greater degrees of instability of many coloured solutions than were at first recognized. King and Garner (1947), for instance, have drawn attention to the fading of the blue colour of the solution used in many bloodsugar methods - a phenomenon which was immediately evident to us when we abandoned the usual visual colorimetric method for evaluating these solutions.

The change which occurs in the sodium determination by the ferrocyanide method is indicated in the Table, which gives the readings obtained on the same solution at different time intervals after adding the ferrocyanide ; the instrument used is the Spekker photo-electric absorptiometer.
TABLE

VARIATION OF SPEK KER READINGS WITH TIME, FOLLOWING ADDITION OF POTASSIUM FERROCYANIDE TO SOLUTION OF TRIPLE ACETATE IN PRESENCE OF ACETIC ACID

\begin{tabular}{c|c}
\hline Time (minutes) & Spekker reading \\
\hline 3 & 0.359 \\
8 & 0.367 \\
13 & 0.377 \\
18 & 0.388 \\
23 & 0.406 \\
28 & 0.427 \\
\hline
\end{tabular}

In view of these changes we decided to examine the method described by Darnell and Walker (1940). In this method the precipitated uranyl zinc sodium acetate, after suitable washing, is dissolved in water and treated with 5 per cent sulphosalicylic acid solution and 10 per cent sodium acetate solution. A clear, bright yellow solution results which we found to be very stable, and the curve given by readings with the Spekker instrument with sodium solutions corresponding to serum sodium concentrations over the range likely to be found in human blood was a straight line. The method has been in use here for some time and has proved to be very satisfactory.

More recently Bradbury (1946) has published a useful simplification of the uranyl zinc acetate procedure. He measured the colour of the super-• natant fluid after the precipitation of the triple acetate, and so determined the reduction of colour produced by the precipitation: this reduction of colour was proportional to the amount of sodium present in the solution examined. This modification effects a useful saving of labour compared with earlier procedures, and, moreover, it avoids possible losses, either mechanical or by solution in 
washing fluid, which are associated with the washing process.

We have found it necessary to make certain alterations in the procedure recommended by Bradbury. We have found that, with the quantities of reagent and alcohol recommended by him, precipitation of the triple salt is by no means complete in the twenty to thirty minutes he specifies. We have increased the proportion of alcohol and generally varied the volumes of fluids used so as to get complete precipitation, and at the same time to have readings of the colour of the supernatant fluid which shall give the most convenient range with the Spekker instrument when applying the method to serum sodium determinations. Even with the increased proportion of alcohol we find it necessary to let the mixture stand for two hours in the refrigerator at approximately $3^{\circ} \mathrm{C}$. to ensure complete precipitation. The readings we have obtained with sodium solutions corresponding to serum concentrations of 200 to $400 \mathrm{mg}$. per $100 \mathrm{ml}$. fall on a straight line.

The full details of the method we use are as follows :

\section{Method}

To $1 \mathrm{ml}$. of serum add $1 \mathrm{ml}$. of water and $1 \mathrm{ml}$. of 20 per cent trichloracetic acid solution. Mix and allow to stand for 10 minutes; filter. To $1 \mathrm{ml}$. of filtrate in a small conical flask add $2 \mathrm{ml}$. of the Weinbach uranyl zinc acetate reagent, ${ }^{1} 3 \mathrm{ml}$. of absolute alcohol, and $2 \mathrm{ml}$. of water. Mix thoroughly; stopper the flask, and allow it to stand in the refrigerator for two hours. Centrifuge the contents of the flask and determine the colour of the supernatant fluid in the Spekker photo-electric absorptiometer, using the Ilford violet filter 601 . Subtract the Spekker reading of this fluid from the reading obtained with a similar mixture except that $1 \mathrm{ml}$. of water replaces the $1 \mathrm{ml}$. of filtrate, and obtain the sodium content of the serum by reading off the difference on the curve obtained by plotting the differences obtained from a series of standard sodium solutions.

\section{REFERENCES}

Barber, H. H., and Kolthoff, I. M. (1928). J. Amer. chem. Soc., 50,

Barber, H. H., and Kolthoff, I. M. (1929). J. Amer. chem. Soc., 51, 3233.

Bradbury, J. T. (1946). J. lab. clin. Med., 31, 1257.

Darnell, M. C., Jr., and Walker, B. S. (1940). Ind. eng. Chem., Anal. Ed., 12, 242.

King, E. J., and Garner, R. J. (1947). J. clin. Path., 1, 30.

King, E. J., and Garner, R. J. (1947). J. clin. Path., 1, 30. 449.

Weinbach, A. P. (1935). J. biol. Chem., 110, 95.

1 Preparation of Weinbach's uranyl-zinc-acetate reagent. Solution A : $77 \mathrm{~g}$. of uranyl acetate and $14 \mathrm{ml}$. of glacial acetic acid are dissolved with gentle heating and stirring in $400 \mathrm{ml}$. of water, and volume made up to $500 \mathrm{ml}$. in a volumetric flask. Solution $B: 231 \mathrm{~g}$. of zinc acetate and $7 \mathrm{ml}$. of glacial acetic acid are dissolved by gentle heating and stirring in $400 \mathrm{ml}$. of water, and volume made up to $500 \mathrm{ml}$. in a volumetric flask. The two solutions are mixed while hot, allowed to stand twenty-four hours or longer, and filtered.

\section{INTERNATIONAL SOCIETY OF HEMATOLOGY}

The International Society of Hematology will hold its biannual meeting at the Hotel Statler, in Buffalo, New York, from August 23 to 26, 1948. The following time has been tentatively allotted for symposia and presentations: half a day on general subjects, including radioactive and stable isotopes in haematology, half a day for problems and diseases related to the red cells, half a day for problems and diseases related to white cells, one day for immuno-haematology, Rh-Hr (CDE-cde) antigens and antibodies and haemolytic anaemias, half a day for coagulation problems and haemorrhagic diseases, and half a day for the business meeting.

Applications for the presentations of scientific exhibits are now being received by Dr. $O$. $P$. Jones, Department of Anatomy, University of Buffalo, - Buffalo, New York. Chairman of the Programme Committee is Dr. Ernest Witebsky, Buffalo General Hospital, Buffalo, New York.
Dr. Eduardo Uribe Guerolo, Leibnitz 212, Nueva Colonia Anzurez, Mexico, D.F., is in charge of the programme from South and Central America, and Sir Lionel Whitby, University of Cambridge, England, is in charge of arrangements for the programme from Europe. Communications concerning applications for the programme will be received by the above-named committee men.

All scientific sessions and exhibits will be open to scientists interested in haematology. This will, of course, include members of the medical profession $N$ and those branches of science dealing with haemato- N logy, such as biochemistry, biophysics, genetics, $\omega$ immunology, etc.

Communications from interested haematologists in 6 the United Kingdom, and applications concerning $\Phi$ membership, should be sent to Dr. Robert R. Race, $\stackrel{f}{?}$ Lister Institute, Chelsea Bridge Road, London, S.W.1. 